IFN Working Paper No. 905, 2012

\title{
Does Religiosity Promote Property Rights and the Rule of Law?
}

Niclas Berggren and Christian Bjørnskov 


\title{
Does Religiosity Promote Property Rights and the Rule of Law?*
}

\author{
Niclas Berggren" ${ }^{\#}$ and Christian Bjørnskov ${ }^{\S}$
}

\begin{abstract}
Social and cultural determinants of economic institutions and outcomes have come to the forefront of economic research. We introduce religiosity, measured as the share for which religion is important in daily life, to explain institutional quality in the form of property rights and the rule of law. Previous studies have only measured the impact of membership shares of different religions, with mixed results. We find, in a cross-country regression analysis comprising up to 112 countries, that religiosity is negatively related to our institutional outcome variables. This only holds in democracies (not autocracies), which suggests that religiosity affects the way institutions work through the political process. Individual religions are not related to our measure of institutional quality.
\end{abstract}

Keywords: Religion, religiosity, rule of law, property rights, institutions

JEL Codes: K11, K42, Z12

\footnotetext{
* We wish to thank Jerg Gutmann, Elena Haramulova, Pavol Minarik, Niklas Potrafke, Petr Špecián, Alois Stutzer, James Vanderhoff, Stefan Voigt, seminar participants at Lund University, the University of Economics in Prague and conference participants at the EPCS meetings in Rennes, the EALE conference in Hamburg, the APSA meetings in Seattle, the SEA conference in Washington, DC, and the Ratio Institute conference on "Property Rights, the Conditions for Enterprise and Economic Growth" for valuable comments and suggestions. Berggren's research is carried out within the Ratio Institute project "Property Rights, the Conditions for Enterprise and Economic Growth" and was partly conducted on a fellowship from the International Centre for Economic Research (ICER) at the Department of Institutional Economics at the University of Economics in Prague. Financial support from Stiftelsen Marcus och Amalia W allenbergs Minnesfond is gratefully acknowledged.

\# Research Institute of Industrial Economics (IFN), P.O. Box 55665, SE-102 15 Stockholm, Sweden; and Department of Institutional Economics, Faculty of Economics, University of Economic in Prague. niclas.berggren@ifn.se.

\Department of Economics and Business, Aarhus University, Hermodsvej 22, DK-8230 Åbyhøj, Denmark. chbj@asb.dk.
} 


\section{Introduction}

Property rights and the rule of law have been shown to be of central importance for economic growth and development. ${ }^{1}$ This result makes it relevant, for anyone concerned about economic growth and development, to study possible determinants of these institutions. In this paper, we explore one possible such determinant, namely religion. Religion is arguably one of the most important social phenomena, and as such, it has become an object of study also in the social sciences, including economics, in recent years.

We try to advance the literature by introducing a factor, religiosity, which has thus far not been used for the purpose of trying to explain institutional quality. We measure this by the share of people in a country for which religion is important in daily life. In contrast, the preceding literature exclusively looks at the effects of belonging to specific religions. We consider it important to broaden the study of religion since we regard it as a multifaceted concept, which covers diverse phenomena, such as the religions to which people belong, the strength of religious beliefs and the heterogeneity of the religious landscape. Looking at merely one of these, as in previous studies, might give too limited insights into the potential importance of religion. For instance, while the shares belonging to particular religions capture certain aspects of religion, these measures may include nominally religious people for whom religious beliefs are not really important and they might miss people with religious beliefs that are not members of any organised religion. Hence, we find it motivated to look at possible effects of religiosity as well (while still controlling for the effects of religious membership, as well as religious diversity). ${ }^{2}$

The particular importance of religion looked at here is one that concerns formal institutions. Might social and cultural variables like religiosity affect the "rules of the game"? We suggest that they might, in affecting beliefs about what is important and desirable and in affecting subsequent behaviour in two dimensions: indirectly, as the way in which the religious behave can have aggregate effects, which affect the perceived need for formal institutions, and directly, as the religious may try to influence the political process. We investigate empirically if this is so by relating our religiosity variable to two de facto measures of the rule of law and property rights (the Heritage and Kaufmann indices). We include both property rights and the rule of law in our study, as there is an intricate and close conceptual relation between these sets of institutions. In the words of Levine $(2005,62)$, “[t]he law,

\footnotetext{
1 The economic importance of legal institutions protecting private property has been documented in a number of studies: see for example North (1981), Rodrik, Subramanian, and Trebbi (2004), Acemoglu and Johnson (2005), Berggren and Jordahl (2005), and Yoo and Steckel (2010).

${ }^{2}$ Separating religious membership and religiosity (how important religion is in daily life) seems important, as Berggren and Bjørnskov (2011) demonstrate that religiosity, but not different types of religion, matters for social trust.
} 
property rights and contracting are inseparable. Statutes define property rights. At a broader level, legal systems consist of the entire apparatus of courts, procedures and institutions associated with enforcing property rights" (see also Hayek 1960, 1973). As the rules per se and their enforcement are intertwined yet separate, this motivates investigating both of these measures alongside each other.

The previous literature has almost exclusively looked at shares of adherents of specific religions, with mixed and conflicting results (for example La Porta et al. 1999, Stulz and Williamson 2003, Levine 2005, Ayyagari, Demirgüç-Kunt, and Maksimovic 2006, and North and Gwin 2010). Using our measure of religiosity in a cross-section of 112 countries, we find that it is negatively related to the institutional outcome variables. In contrast, other aspects of religion that we control for, membership shares of the large religions and religious diversity, do not attain significance.

We expand the analysis in two ways. First, by clarifying causality by means of instrumental variables, since religiosity might affect the quality of institutions and since the quality of institutions might affect religiosity. While we do not rule out a complex interrelationship, we find support for the former causal direction. Second, we allow the effect of religiosity on the rule of law and property rights to vary according to the degree of democracy, to learn more about the mechanism underlying the relationship between religiosity and institutional quality. We find that the effect is larger the stronger the degree of democracy and non-existent in autocracies. This can be interpreted as a willingness of political decision-makers in a democratic setting to adapt and cater to religious voters and interest groups.

\section{A Theoretical Primer}

How may religiosity, in the sense of religion being important to people, influence the rule of law and property rights? We propose that religiosity can influence the politicians who design institutions and make policy within the framework provided by them. This influence is multifaceted, as portrayed in Figure 1.

First, religious voters can affect politicians in office both directly and indirectly, and through the act of voting they help determine who gets elected. The direct influence stems from religiously coloured political views, which either the religious consciously and actively give voice to in the political process or which are simply passively held but catered to by politicians striving for the support of voters. One reason that politicians might care is if either the median voter holds strong religious beliefs or if groups that are sufficiently large to be politically interesting do so. The indirect influence comes about by religious people's general behaviour being such that it affects the perceived need for formal institutions. If a large portion of the population is religious and if this has bearing on variables like honesty, trust 
and criminality levels in society, this could make decision-makers care more or less about economic and legal rules and systems of enforcement of those rules.

Second, the religious may form and be active in interest groups that likewise attempt to convince policymakers to take their positions into account, in exchange for some type of support. This could be in the form of religious organizations, like established churches, or more cause-oriented groups. Interest groups are most usually thought of as constituting minorities that try to affect policymakers on specific issues - and this may be the case for religiosity as well. That is, even if the median voter or large groups of voters are not religious, interest groups will still try to succeed with their causes (perhaps especially then, since their efforts are not needed as much otherwise). However, it could also be that the median voter and large groups of voters are religious, that religious interest groups are advocating the same institutional design as decisive or that religious positions are assigned more moral authority. In such cases, the religious influence will be even greater.

Lastly, the politicians themselves can, in addition to responding to the views of religious voters and interest groups, be religious and experience a personal preference for following a religious belief in their legislative activities. If the politicians thereby are in personal alignment with a religious median voter, large groups of religious voters and religious interest groups, this will make the influence of these actors even stronger and more straightforward. If the politicians, in contrast, are religious while the median voter or a large majority of voters are not, then the politicians may opt for institutions based on their religiosity at a cost (a risk of losing votes). This is a price they may be willing to pay; and in any case, they may thereby yield support from religious interest groups that may be used to regain votes. Regardless, the actual decision-making then takes place within the framework of given political institutions, resulting in a certain rule of law and a certain system of property rights. ${ }^{3}$

The next question concerns what religiosity implies about what the rule of law and property rights should be. One could envisage theoretical reasons both for a positive and a negative effect on the quality of institutions. ${ }^{4}$

First, why expect a positive effect? We see at least two possible mechanisms. One is a general element of virtually all religions, namely the propagation of ethical teachings which stress that honesty, generosity and fairness towards all are highly virtuous attributes and that prohibit certain types of behaviour, such as cheating or theft, which are likewise embodied in the rule of law and the legal

\footnotetext{
${ }^{3}$ This reasoning is broadly in line with the model of Acemoglu, Johnson, and Robinson (2005).

${ }^{4}$ Note that we do not consider the beliefs of particular religions but religious beliefs and practices that we believe to be common to most religious people.
} 
protection of property rights. ${ }^{5}$ Similarly, the idea of punishment is prevalent in most religions, both in this life (from social methods to physical ones) and in the afterlife (for example in the form of purgatory, hell or rebirth as something less flattering). The attitudes of the faithful may thus be geared towards an acceptance of and support for formal institutions that provide rules and enforcement similar to that espoused in their religions. Add to that some findings that indicate a deference to authority in religious circles (see for example Mueller 2009, Fere and Klanjšek 2009, Wisneski, Lytle, and Skitka 2009, and Putnam and Campbell 2010), which suggest that the legal apparatus and the government more generally are seen as desirable, stabilizing features of an unsafe existence. Moreover, if the religious are indeed more likely to abide by rules or have a strong intrinsic motivation not to commit crimes, this would ease the resource constraint on legal systems, which could increase quality.

Another possible mechanism pointing at a positive relationship has been formulated by Hayek (1991, 137):

\begin{abstract}
The undoubted historical connection between religion and the values that have shaped and furthered our civilization, such as the family and several property, does not of course mean that there is any intrinsic connection between religion as such and such values. Among the founders of religions over the last two thousand years, many opposed property and the family. But the only religions that have survived are those which support property and the family.
\end{abstract}

That is, through a process of cultural evolution, societies that have honoured property rights have been able to flourish and survive, whilst other societies, and the anti-property teachings and practices that characterised them, have disappeared. This suggests that present-day religiosity is positively tied to a strong protection of property rights and, by implication, a strong rule of law.

However, there are also arguments as to why religiosity can exert a negative influence. We will briefly mention seven such arguments. First, a religious outlook on life tends to entail anti-materialism and a focus on the eternal; one possible view is that all material things are really the possessions of some god (Wilson 1997). This could manifest itself in a disinterest in or hostility towards formal institutions, an important motive for which is to secure the growth of possessions and wealth. Second, a common view among the religious is that the rich have a moral obligation always to help the poor, and strict protection of property rights seems to go against this ethical position. Third, the religious tend to divide behaviour into good or bad, and to the extent that the rich are perceived as having

\footnotetext{
${ }^{5}$ Berggren (1997), Iannaccone (1998), and Baier and Wright (2001) report negative associations between religiosity and crime (but see Heaton 2006 for a dissenting view). Commands or rules that promote honesty and prohibit theft and the like can be found in virtually all the major world religions - see Wattles (1996) and Putnam and Campbell (2010, 463).
} 
acquired their wealth or high incomes in "sinful" ways, such as through usury, this could weaken support for a strong protection of property rights. Fourth, as mentioned above, there is in general, among religious people, a belief in reward and punishment in an afterlife, either through an eternal state of suffering or through rebirth as something less pleasant (McCleary and Barro 2006). While this could create some sympathy for a legal order, we here suggest that it, to the contrary, can cause the faithful to regard worldly punishment as less important, since justice will be metered after death.

Fifth and partly related to the former point, religiosity and formal institutions can be substitutes in the provision of orderly conduct. This could come about through the belief of the religious in divine or cosmic punishment if transgressions are undertaken, or through the expectation that religious organizations or individuals in their vicinity will punish those who behave badly. It could also arise due to an internalization of the devout of ethical rules to the effect that they do not wish to behave in a socially destructive way. In effect, their preferences have been shaped in such a manner. If people in general, due to the prevalence of the religiously based mechanisms, shy away from opportunistic behaviour of various kinds, this makes the perceived need for formal institutions of law and order weaker (Iannacone 1998). Sixth, religiosity seems negatively related to social trust (Berggren and Bjørnskov 2011), and since trust is beneficial for general agreement and the production of public goods (Putnam 1993, Hull and Bold 1994), like the rule of law, this suggests that religiosity stands in a negative relationship to that kind of goods. Seventh, we note the possibility that religious organizations may consider strong legal systems as competitors. Most religions aim at enforcing specific rules and teachings, some of which are also enforced by modern judiciaries and legal organizations. Organised religions that provide a form of informal protection of property rights may therefore perceive developments towards stronger and more independent judiciaries as a threat to their power base. They may, for this reason, have a special-interest incentive to work against particularly strong formal institutions, and may be more successful the more voters are religious.

This leaves us with a simple theoretical structure of how religiosity affects the design and practical use of formal institutions in the political process, through voters, interest groups and politicians, partly due to the convictions of the religious and the catering of politicians to those convictions, either because they share them or to secure votes, and partly due to behavioural effects that influence the perceived need for formal institutions. It bears noting that the theoretical prediction as to whether the relationship is positive or negative overall is ambiguous, which calls for empirical analysis. 


\section{Data}

In order to test our overall hypotheses, we draw data from a number of different sources. First, we use two different measures of property rights protection and the rule of law. Both are de facto measures and can therefore be seen as indicators of enforcement quality. Measuring the quality of institutions is not an easy task - one problem being that measures are subjective - which is why we opt for two rather different approaches to construct such measures, with opposite strengths and weaknesses.

Our first choice is the Heritage Foundation (2010) measure of the protection of property rights, which measures the strength of property rights protection; it goes from 0 (no protection) to 100 (full protection) with New Zealand at the top (95 points) and Venezuela at the bottom ( 0 points). However, although the Heritage index is conceptually "clean" in the sense that it clearly aims at measuring the de facto protection of private property rights, the way it is practically coded is not fully transparent. We therefore supplement the Heritage index with the World Governance Indicators measure of the "rule of law" (Kaufmann, Kraay, and Mastruzzi 2008). This index also measures the quality of institutions protecting property rights, but its construction is more transparent. It is, on the one hand, constructed by merging information from a large number of primary indices, which ought to reduce the inherent noise of the index. On the other hand, compared to the Heritage index, recent tests suggest that the World Governance Indicators tend to lack conceptual differentiation (Knack and Langbein 2010). We prefer to remain agnostic with respect to the relative merits of each index and provide results for both throughout the paper.

Our measure of religiosity comes from the Gallup World Poll (Gallup 2009). The poll asked respondents "Is religion an important part of your daily life?" and our measure is the share of the population that answered "yes" to this question. The validity of the question as a measure of religiosity, salience and strength of beliefs has been previously corroborated (Halman and Draulans 2006), making it a good complement to other measures in the literature. We furthermore prefer this to more specific measures, such as beliefs in hell or an afterlife, since these beliefs tend to be specific to certain religions and since data are not available for a broader country sample.

We control for two other aspects of religion. Relating to the previous literature, we include the share of populations belonging to Protestant, Catholic or Orthodox Christianity, Islam or an Eastern religion (Buddhism and Hinduism). We get these data from CIA (2010), supplemented by USDS (2009). We also use a measure of religious diversity, deriving from Alesina et al. (2003). The index is calculated as one minus the Herfindahl-Hirschman index of the composition of religious affiliations in the population. 
We include a battery of further control variables. As is standard, we use the logarithm to purchasing-power adjusted GDP per capita and openness measured as trade volumes; both variables derive from Heston, Summers, and Aten (2006). We also add social trust (Uslaner 2002, Berggren and Bjørnskov 2011) and a set of dummies for three categories of legal origins, following Glaeser and Shleifer (2002): common law, civil law and the particular mixed Scandinavian tradition. The latter also effectively controls for whether results are likely to be driven by Scandinavia, which is the region of the world with the lowest levels of religiosity. We use dummies for five regions: Asia, Latin American and the Caribbean, North African and the Middle East, Sub-Saharan Africa, and the post-communist countries of Central and Eastern Europe.

In addition, we control for the level of democracy or political competition, following Aghion, Alesina, and Trebbi (2004) and Bjørnskov (2010). We do this by categorizing democracy in four levels depending on (1) if the Polity IV index is above 5; (2) if the Herfindahl-Hirschman index of the legislature is below .7; (3) if the country does not have a presidential system; and (4) if, in this case, the political system is not characterized by a president with substantial discretionary power (Bjørnskov, 2010, 335). These criteria are successively added up to form an index between 1 and 4 . The logic in the present context can be described as follows. The first criterion roughly ensures that countries are formally democratic, that is, that they hold free and fair elections at regular intervals. Given that (1) holds, the second condition captures the degree to which formal democracy is accompanied by actual political competition. Finally, we differentiate the score between parliamentary (two points), weak (one point) and strong presidential systems in the last two conditions. In our particular setting, drawing this distinction might be important as stronger presidential systems imply that the religious beliefs of the president might be able to dominate the political process. For this variable, countries are fairly evenly distributed across our sample, with 21 countries in category 1, 39 in category 2, 33 in category 3 , and 23 in category 4.

To test whether potential effects run through the political system, we also provide a set of interactions between this measure of democracy and religiosity, which provides information on whether or not potential effects are likely to run through the political process or not. For the central interaction results, we provide the point estimates and conditional standard errors for all four categories of democracy using the delta method (Brambor, Clark, and Golder 2006).

We report results estimated with OLS throughout, supplemented by a set of 2SLS estimates using confidence in religious organizations and a dummy for the Nordic countries as instruments. The reason is that this kind of confidence is a by-product of religiosity and that Nordic countries are less religious for other reasons than property rights protection. 
All data are summarised in Table 1.

\section{Empirical Results}

We start by simply plotting the relation between religiosity and the Kaufmann index in Figure 2. As our theoretical prior is that part or all of the relation is mediated through the political process, we exhibit the simple regression lines through the subsamples with low and high levels of political competition, respectively. The relation does seem to depend on political competition, and is especially negative in the highly democratic countries. However, other factors that are correlated with religious characteristics may well drive some of these differences, and we therefore now turn to regression analysis.

\subsection{Main Results}

We estimate the association in a cross-section of countries with full data; results are reported in Table 2. We first note that our main controls turn out as in the bulk of the literature: richer and more open countries without a communist past tend to have significantly better property rights protection and rule of law. For both indices, we find a clear, positive association with the measure of democracy: a onepoint change in political competition is associated with an improvement of approximately 15 percent of a standard deviation in both cases. Social trust, on the other hand, is not significant except in column 4. ${ }^{6}$ We also find clear evidence of regional differences but no differences across legal origins. With respect to the standard religious variables, we neither find evidence of an effect of religious diversity nor of affiliation shares. The latter are jointly insignificant, and none of them are individually significant. ${ }^{7}$

However, we find strong support for a negative and sizeable effect of religiosity on the Heritage index of property rights protection, and somewhat weaker evidence of a likewise negative effect on the other index. Hence, what seems to matter for an effect of religion on the design of formal institutions, like the rule of law and property rights, is not the dominant religion per se but the level of religiosity.

\footnotetext{
${ }^{6}$ The missing association between institutional quality and trust is a consequence of treating it as homogenous. Knack (2002) and Bjørnskov (2010) argue that there is a strong association in the democratic half-sample but no clear association in the other half. As it does not affect our main results, we do not make this distinction in our analysis.

${ }^{7}$ While we find no differences between any religions, our sample does not include examples of outright theocracies, like Iran. Certain Middle Eastern societies within the sample, as for example Saudi Arabia, may be considered Muslim semitheocracies, yet these societies are not distinguishable from other non-democratic countries with a resource-based economy.
} 
The larger the share for which religion is an important part of daily life, the weaker the rule of law and the protection of property rights. As far as we know, this is a new result in the literature. ${ }^{8}$

\subsection{Conditional Associations and Causality}

While we find some evidence of a negative effect of the strength of religious beliefs, two qualifications may apply: whether associations only arise under some conditions and whether they are causal. Figure 2 and our theoretical considerations point to potentially heterogeneous effects depending on the type of political institutions. We focus on the degree of democratic political competition, which differs between countries. ${ }^{9}$ The direct effect on the rule of law and property rights can be expected to be positive: mature democracies with popular representation plausibly employ high-quality and fair legal systems (O’Donnell 2004, Rigobón and Rodrik 2005). There may be a secondary effect of political competition, however, in the sense that it can also influence the size of the effect of religiosity, although it is not theoretically clear in what direction. In autocracies with no political competition, religiosity would influence the legal and economic institutions more if the autocratic leadership was either religious themselves or open to religious sentiments in the population. In a democracy, on the other hand, the model of Figure 1 applies straightforwardly, and if there are many religiously devout people, the effect of religiosity can be expected to be strong.

We test the possibility of interaction effects in Table 3, where all regressions include the full baseline specification from Table 2 and where columns 1 and 3 in Table 3 report the main estimates from Table 2. As can be seen, there is a negative interaction effect. To better grasp the distribution and size of the effect, we present estimates with conditional standard errors calculated by the delta method (Brambor, Clark, and Golder 2006) for the four levels of democracy in Table 4. The OLS estimates show clear evidence of heterogeneity: they are significant in categories three and four in which countries have both free elections and some level of political competition, but not in categories one and two, with no or little political competition. Effects of religiosity on protection of property rights in democratic countries are not only of statistical significance, but of economic and political significance too. At political competition level 4 (3), a one standard deviation increase in religiosity is associated

\footnotetext{
${ }^{8}$ We have tested whether the effect of religiosity is stronger in countries dominated by certain religions. When we compare the DFBetas of countries with different majority religions, we do not find any clear differences, supporting our contention that religiosity, rather than individual religions, that matters.

${ }^{9}$ Political competition has been shown to be central, in the U.S. context, for the adoption of growth-promoting policies (Besley, Persson, and Sturm 2010); and Bjørnskov (2010) finds that the positive effect of social trust on the quality of governance varies with the degree of political competition.
} 
with a decline in the Heritage index of 42 percent ( 26 percent); with the Kaufmann index, a similar increase results in a 28 percent (16 percent) decline. In comparison, effects of a one standard deviation increase in religiosity with both indices in full democracy are slightly larger than the effect of a one standard deviation decrease in GDP per capita. These findings suggest that the negative effect of religiosity on the rule of law and property rights protection comes about through the democratic political process, as religion affects voters, interest groups and politicians.

We have so far interpreted the associations as causal, although there are also theoretical arguments for a reverse causal direction. For example, it could be that property rights and the rule of law are associated with a widespread feeling of certainty and security which reduces the need for the comfort that religiosity might bring. We address this potential problem in Table 5 , in which we report 2SLS estimates of religiosity. The instrumental variables identifying religiosity in the first stage are average confidence in religious organizations and a dummy for the Nordic countries (Denmark, Iceland, Finland, Norway and Sweden). We note several reasons why we believe the instruments are likely to be valid. The Nordic countries do not have different property rights protection than other countries at the same level of economic development; and religious organizations are de facto independent of government formal institutions (although all of them except Sweden have de jure state churches). Confidence in these organizations ought therefore not to depend on the quality of formal legal institutions as they are formally and practically separate organizations with entirely separate purposes. Both of these instruments are furthermore related to religiosity (negatively and positively).

In our causality tests, the validity and strength of our instruments are supported by strong first stage statistics and clearly insignificant Hansen's J statistics. The estimates are very similar to those obtained by OLS. Religiosity remains overall significantly negative in columns 1 and 3, while results in columns 2, 4 and again suggest that effects only appear in countries with sufficient levels of political competition. Table 4 also reports 2SLS estimates across the four categories for direct comparison. For both indices, the instrumental estimates if anything imply stronger effects, yet the difference compared to the OLS results is not significant. As far as instrumental variables can inform about causality, we believe that these estimates can be interpreted as causal effects of religiosity on the enforcement quality of formal institutions through the political process. This being said, we do not rule out a causal effect in the other direction. ${ }^{10}$

\footnotetext{
${ }^{10}$ As specific choices for instrumental variables can always be questioned, we have rerun estimates with other sets of instruments. While not as clearly identified, urban population and dummies for Muslim, Catholic and Orthodox countries provide alternative identification with reasonable test statistics (First stage $F=4.26$; Hansen $\mathrm{J}$ stat $=3.627$; $\mathrm{p}<.305$ ), which yields a point estimate of religiosity of -1.638 (std.err. .732).
} 


\subsection{Further Sensitivity Analysis}

While our estimates are significant and quite sizeable, they could nonetheless be spurious for several reasons. In this section, we provide a sensitivity analysis exploring three sources of such bias: 1) alternative measures; 2) model specification; and 3) outlier influence. We start by employing two alternative measures of religiosity in Tables 6 and 7 .

In Table 6, we replace the importance of religion in daily life with the share of non-believers (atheists and agnostics) in the population. While we find that this share is not significant at the sample mean or when interacted with religious diversity, the interactions with political competition tell the same basic story as in previous tables. With both indices, effects are strongly significant at the top level of democracy and weakly significant (at the 10 percent level) in category 3 . In Table 7, we instead use weekly attendance rates at religious services as a proxy for religiosity. Similarly to previous tables, the interactions with political competition strongly support systematic heterogeneity.

The estimates suggest that a one-standard deviation change in either religiosity indicator is associated with a decline in property rights protection and the rule of law of somewhere between 25 and 40 percent of a standard deviation with full democracy, depending on the choice of indicator. We also find support for effects at the next level of political competition but no unambiguous evidence of effects in countries without some level of political rights. In all, we think these alternative measures indicate a fairly robust negative effect of religiosity in settings with strong democracy.

We finally turn to the issue of potential outliers, which we identify in two different ways: 1) we exclude observations from our sample based on Cook's D (larger than 1.5 standard deviations); and 2) we exclude the tails of the distributions (the top and bottom deciles) of property rights and religiosity. We report the results of this exercise in Table 9.

Columns 1 and 4 first report the results of removing obvious outliers, as identified by Cook's D. With the Heritage index, we find six outliers, while the Kaufmann index yields one more. However, the central results are clearly not driven by these observations since the main results are unchanged from previous tables. In columns 2 and 5, we explore if the results are driven by observations in the tail of the distribution of religiosity, while columns 3 and 6 report the results of excluding the tails of the distributions of our indices. In either case, we test for the degree to which results generalize to most of the sample. Our results also prove robust to these tests. We therefore conclude that our main result that religiosity is significantly negatively associated with the quality of economic-judicial enforcement institutions in democracies - is robust to standard sensitivity tests. 


\section{Concluding Remarks}

We have explored the cross-country association between religiosity and two indices of the de facto protection of property rights. Whereas the previous empirical literature has utilised religious membership shares as their measure of religion, with ambiguous findings, we introduce religiosity (measured as the share of people in different countries that indicate that religion is an important part of daily life) as a new aspect of potential relevance for institutional quality.

One can expect religiosity to affect formal institutions through the political process. Religiosity influences voters, who may try to influence politicians either directly or through interest groups and towards whom politicians may extend proposals that appeal to them, given their convictions. For that matter, politicians can be influenced by religiosity themselves in a way that affects their positions on institutional design and practice. In addition, religiosity can affect aggregate behaviour, for example with respect to criminality, in a way that has bearing on the perceived need for formal institutions.

Speaking in favour of a positive effect of religiosity is the widespread acceptance of rules and authority among the religious and an evolutionary argument that only societies with religions accepting the rule of law and property rights have survived. Speaking in favour of a negative relationship is, among other things, that religiosity often entails anti-materialism and other-worldliness; that religions tend to favour redistribution from the rich to the poor; that the religious believe in justice in an afterlife, which reduces the need for justice on earth; that order can be provided through religious rules and preferences, such that formal institutions are not perceived to be needed; that religiosity is negatively related to social trust, which implies difficulties agreeing on the production of public goods; and that religious organizations may regard formal institutions as competitors.

In the empirical analysis, we find a clear, negative and statistically significant effect of the importance of religion in daily life on two institutional measures. Furthermore, religious membership shares over countries are not in general statistically significant, which implies that it is not religious membership per se that matters but the degree to which religion is taken seriously. Then, people feel a strong motivation to adhere to their religious beliefs and to try to make others adhere to them. Hence, one can expect involvement in the political process from the religiously devout, with effects on institutional design. Through an instrumental-variables approach, we find support for a causal effect. Although we cannot rule out that institutional quality has some feedback effect on religiosity as well, we note that OLS estimates seem unbiased, which one would expect them not to be in the presence of strong reverse causality.

We interact religiosity with a political competition index, which can be seen as a measure of democracy, in order to see if the effect stems from the political system. We find that the higher the 
degree of political competition, the larger the negative effect of religiosity, which suggests that in democratic settings, the religiously devout are more successful in "getting their way". This interpretation is moreover supported by the fact that we do not find any robust evidence of effects in non-democratic countries. In addition, we have carried out a sensitivity analysis, by using alternative measures of religiosity, by including additional control variables and by deleting outliers, and the results largely confirm our main findings.

In all, our results provide new evidence of the social, political and economic effects of religion, adding to a growing field of cross-disciplinary research. Future studies could delve deeper into the precise mechanisms behind a negative effect of religiosity - for example with regard to how political influence is achieved by the devout and whether religiosity affects behaviour which in turn affects institutional design. Likewise, a time dimension could be introduced as more data become available.

\section{References}

Acemoglu, Daron, and Simon Johnson. 2005. Unbundling Institutions. Journal of Political Economy 113:949-95. Acemoglu, Daron, Simon Johnson, and James A. Robinson. 2005. Institutions as a Fundamental Cause of LongRun Growth. Pp. 385-472 in Handbook of Economic Growth, Volume 1A, edited by Philippe Aghion and Steven N. Durlauf. Amsterdam: Elsevier.

Aghion, Philippe, Alberto Alesina, and Francesco Trebbi. 2004. Endogenous Political Institutions. Quarterly Journal of Economics 119:565-611.

Alesina, Alberto, Arnoud Devleeschauwer, William Easterly, Sergio Kurlat, and Romain Wacziarg. 2003.

Fractionalization. Journal of Economic Growth 8:155-94.

Argyle, Michael. 1958. Religious Behaviour. London: Routledge.

Ayyagari, Meghana, Asli Demirgüç-Kunt, and Vojislav Maksimovic. 2006. How Well Do Institutional Theories Explain Firms' Perceptions of Property Rights? Review of Financial Studies 21:1833-871.

Baier, Colin J., and Bradley R. E. Wright. 2001. 'If You Love Me, Keep My Commandments': A Meta-Analysis of the Effect of Religion on Crime. Journal of Research in Crime and Delinquency 38:3-21.

Barro, Robert J., and Rachel M. McCleary. 2005. Which Countries Have State Religions? Quarterly Journal of Economics 120:1331-70.

Berggren, Niclas. 1997. Rhetoric or Reality? An Economic Analysis of the Effects of Religion in Sweden. Journal of Socio-Economics 26:571-96.

Berggren, Niclas, and Christian Bjørnskov. 2011. Is the Importance of Religion in Daily Life Related to Social

Trust? Evidence from Cross-Country and Cross-State Comparisons. Journal of Economic Behavior \& Organization 80:459-80.

Berggren, Niclas, and Henrik Jordahl. 2005. Does Free Trade Really Reduce Growth? Further Testing Using the Economic Freedom Index. Public Choice 122:99-114. 
Besley, Timothy, Torsten Persson, and Daniel M. Sturm. 2010. Political Competition, Policy and Growth: Theory and Evidence from the U.S. States. Review of Economic Studies 77:1329-52.

Bjørnskov, Christian. 2008. The Growth-Inequality Association: Government Ideology Matters. Journal of Development Economics 87:300-08.

------. 2010. How Does Social Trust Lead to Better Governance? An Attempt to Separate Electoral and Bureaucratic Mechanisms. Public Choice 144:323-46.

Brambor, Thomas, William R. Clark, and Matt Golder. 2006. Understanding Interaction Models: Improving Empirical Analysis. Political Analysis 14:63-82.

CIA. 2010. CIA World Factbook, 2010. Langley, VA: Central Intelligence Agency.

Fere, Sergej, and Rudi Klanjšek. 2009. Cross-Cultural Insight into the Association between Authoritarianism and Religiousness. Archives for the Psychology of Religion 31:177-90.

Gallup. 2009. Gallup World Poll. http://www.gallup.com/consulting/worldpoll/24046/About.aspx. Hayek, Friedrich A. 1960. The Constitution of Liberty. Chicago, IL: University of Chicago Press.

-----. (1973). Law Legislation and Liberty: Rules and Order. London: Routledge.

-----. (1991). The Fatal Conceit: The Errors of Socialism. Chicago, IL: University of Chicago Press.

Heaton, Paul. 2006. Does Religion Really Reduce Crime? Journal of Law \& Economics 49:147-72.

Heritage Foundation. 2010. 2010 Index of Economic Freedom. Washington, DC: Heritage Foundation.

Heston, Alan, Robert Summers, and Bettina Aten. 2006. Penn World Tables Mark 6.2. Philadelphia: Center for International Comparisons of Production, Income and Prices, University of Pennsylvania.

Hull, Brooks B., and Frederick Bold. 1994. Hell, Religion, and Cultural Change. Journal of Institutional and Theoretical Economics 150:447-64.

Iannaccone, Lawrence R. 1998. Introduction to the Economics of Religion. Journal of Economic Literature 36:146596.

Kaufmann, Daniel, Aart Kraay, and Massimo Mastruzzi. 2008. Governance Matters VII: Aggregate and Individual Governance Indicators 1996-2007. World Bank Policy Research Working Paper no. 4654. The World Bank, Washington DC.

Knack, Stephen. 2002. Social Capital and the Quality of Government: Evidence from the U.S. States. American Journal of Political Science 46:772-85.

Knack, Stephen, and Laura Langbein. 2010. The Worldwide Governance Indicators and Tautology: Six, One, or None? Journal of Development Studies 46: 350-70.

La Porta, Rafael, Florencio Lopez-de-Silanes, Andrei Shleifer, and Robert W. Vishny. 1999. The Quality of Government. Journal of Law, Economics \& Organization 15:222-79.

Levine, Ross. 2005. Law, Endowments and Property Rights. Journal of Economic Perspectives 19:61-88.

Lynn, Richard, John Harvey, and Helmuth Nyborg. 2008. Average Intelligence Predicts Atheism Rates across 137 Nations. Intelligence 37:11-15.

McCleary, Rachel M., and Robert J. Barro. 2006. Religion and Economy. Journal of Economic Perspectives 20:49-72. 
Mueller, Dennis C. 2009. Reason, Religion, \& Democracy. Cambridge, UK: Cambridge University Press.

North, Douglass C. 1981. Structure and Change in Economic History. New York: Norton.

North, Charles M., and Carl R. Gwin. 2010. Religion and the Emergence of the Rule of Law. Pp. 127-56 in Religion, Economy, and Cooperation, edited by Ilkka Pyysiäinen. Berlin: De Gruyter.

Nyborg, Helmuth. 2008. The Intelligence-Religiosity Nexus: A Representative Study of White Adolescent Americans. Intelligence 37:81-93.

O’Donnell, Guillermo A. 2004. Why the Rule of Law Matters. Journal of Democracy 15:32-46.

Putnam, Robert D. 1993. Making Democracy Work: Civic Traditions in Modern Italy. Princeton, NJ:

Princeton University Press.

Putnam, Robert D., and David E. Campbell. 2010. American Grace: How Religion Divides and Unites Us. New York: Simon \& Schuster.

Rigobón, Roberto and Rodrik, Dani. (2005). 'Rule of law, democracy, openness, and income: estimating the interrelationships', Economics of Transition, vol. 13(3), pp. 533-564.

Rodrik, Dani, Arvind Subramanian, and Francesco Trebbi. 2004. Institutions Rule: The Primacy of Institutions over Geography and Integration in Economic Development. Journal of Economic Growth 9:131-65.

Wattles, Jeffrey. 1996. The Golden Rule. Oxford, UK: Oxford University Press.

Wilson, Rodney. 1997. Economics, Ethics and Religion: Jewish, Christian and Muslim Economic Thought. New York: New York University Press.

Wisneski, Daniel C., Brad L. Lytle, and Linda J. Skitka. 2009. Gut Reactions: Moral Conviction, Religiosity, and Trust in Authority. Psychological Science 20:1059-63.

Yoo, Dongwoo, and Richard H. Steckel. 2010. Property Rights and Financial Development: The Legacy of Japanese Colonial Institutions. Working Paper no. 16551. Cambridge, MA: NBER. 
Table 1

Descriptive Statistics

\begin{tabular}{lccccc}
\hline & Mean & $\begin{array}{c}\text { Standard } \\
\text { deviation }\end{array}$ & Minimum & Maximum & Observations \\
\hline Log GDP per capita & 8.763 & 1.122 & 6.242 & 10.783 & 114 \\
Openness & 78.834 & 47.372 & 18.240 & 337.859 & 114 \\
Postcommunist & .216 & .412 & 0 & 1 & 116 \\
Elkins index & 2.982 & 1.186 & .286 & 6.071 & 96 \\
Heritage index & 50.351 & 24.374 & 0 & 95 & 114 \\
Kaufmann index & .167 & .982 & -1.811 & 1.965 & 116 \\
Civil law & .603 & .491 & 0 & 1 & 116 \\
Common law & .250 & .435 & 0 & 1 & 116 \\
Scandinavian law & .043 & .204 & 0 & 1 & 116 \\
Political competition & 2.500 & 1.009 & 1 & 4 & 116 \\
Social trust & 25.483 & 13.466 & 3.400 & .860 & 116 \\
Religious diversity & .424 & 2.35 & .002 & 1 & 116 \\
Nordic countries & .043 & .204 & 0 & 95 & 107 \\
Confidence in religion & 68.234 & 15.623 & 16 & 100 & 116 \\
Muslim & 19.472 & 31.783 & 0 & 98 & 116 \\
Orthodox & 11.767 & 27.054 & 0 & 95 & 116 \\
Protestant & 15.022 & 23.779 & 0 & 98 & 116 \\
Catholic & 30.266 & 36.561 & 0 & 95 & 116 \\
Eastern & 5.776 & 19.733 & 0 & 1.00 & 116 \\
State religion & .423 & .496 & 0 & .16 & 114 \\
Religiosity & .683 & .254 & & & 116 \\
\hline
\end{tabular}


Table 2

Main Results

\begin{tabular}{|c|c|c|c|c|}
\hline & \multicolumn{2}{|c|}{ Heritage Property Rights } & \multicolumn{2}{|c|}{ Kaufmann Rule of Law } \\
\hline & (1) & $(2)$ & (3) & (4) \\
\hline \multirow[t]{2}{*}{ Log GDP per capita } & $8.516^{* * *}$ & $8.574 * * *$ & $.428^{* * *}$ & $.435^{* * *}$ \\
\hline & $(2.675)$ & $(2.658)$ & $(.081)$ & $(.078)$ \\
\hline \multirow[t]{2}{*}{ Openness } & $.052 *$ & $.053 * *$ & $.002 * *$ & $.002 * * *$ \\
\hline & $(.029)$ & $(.026)$ & $(.001)$ & $(.001)$ \\
\hline \multirow[t]{2}{*}{ Postcommunist } & $-20.997 * * *$ & $-24.321 * * *$ & $-.615^{* * *}$ & $-.700 * * *$ \\
\hline & $(4.980)$ & $(4.915)$ & $(.165)$ & $(.165)$ \\
\hline \multirow[t]{2}{*}{ Political competition } & $3.425^{* *}$ & $4.116^{* * *}$ & $.147 * *$ & $.169 * * *$ \\
\hline & $(1.608)$ & $(1.520)$ & $(.062)$ & $(.058)$ \\
\hline \multirow[t]{2}{*}{ Social trust } & -.023 & .042 & .005 & $.007^{*}$ \\
\hline & $(.132)$ & $(.114)$ & $(.004)$ & $(.004)$ \\
\hline \multirow[t]{2}{*}{ Religious diversity } & -3.489 & 1.391 & -.020 & .022 \\
\hline & $(7.522)$ & $(6.234)$ & $(.301)$ & $(.219)$ \\
\hline \multirow[t]{2}{*}{ Muslim } & -.057 & & -.001 & \\
\hline & $(.092)$ & & $(.003)$ & \\
\hline \multirow[t]{2}{*}{ Orthodox } & -.068 & & -.001 & \\
\hline & $(.088)$ & & $(.003)$ & \\
\hline \multirow[t]{2}{*}{ Protestant } & .066 & & .002 & \\
\hline & $(.104)$ & & $(.004)$ & \\
\hline \multirow[t]{2}{*}{ Catholic } & -.019 & & .001 & \\
\hline & $(.075)$ & & $(.003)$ & \\
\hline \multirow[t]{2}{*}{ Eastern } & .053 & & .002 & \\
\hline & $(.081)$ & & $(.003)$ & \\
\hline \multirow[t]{2}{*}{ Religiosity } & $-17.346^{*}$ & $-20.999 * *$ & -.418 & $-.484 *$ \\
\hline & $(10.049)$ & $(8.979)$ & $(.328)$ & $(.278)$ \\
\hline Regional effects & Yes & Yes & Yes & Yes \\
\hline Observations & 111 & 111 & 112 & 112 \\
\hline Adjusted R square & .759 & .746 & .826 & .820 \\
\hline F statistic & 66.15 & 58.71 & 95.65 & 92.20 \\
\hline RMSE & 13.28 & 13.08 & .456 & .444 \\
\hline Legal origins joint $F$ & .76 & & .09 & \\
\hline Region joint $\mathrm{F}$ & $2.99 * *$ & $2.87 * * *$ & $8.75^{* * *}$ & $8.77 * * *$ \\
\hline Religion joint $\mathrm{F}$ & .76 & & 1.02 & \\
\hline
\end{tabular}

Note. Heteroscedasticity consistent standard errors in parentheses.

$$
\begin{aligned}
& \text { *** } P<.01 . \\
& * * P<.05 \\
& * P<.10 .
\end{aligned}
$$


Table 3

Main and Interacted Results

\begin{tabular}{|c|c|c|c|c|}
\hline & \multicolumn{2}{|c|}{ Heritage Property Rights } & \multicolumn{2}{|c|}{ Kaufmann Rule of Law } \\
\hline & (1) & (2) & (3) & (4) \\
\hline \multirow[t]{2}{*}{ Political competition } & $4.116^{* * *}$ & $14.319^{* * *}$ & $.169^{* * *}$ & $.492^{* * *}$ \\
\hline & $(1.520)$ & $(3.430)$ & $(.058)$ & $(.119)$ \\
\hline \multirow[t]{2}{*}{ Religiosity } & $-20.999 * *$ & 20.038 & $-.484^{*}$ & .807 \\
\hline & $(8.979)$ & $(16.169)$ & $(.278)$ & $(.524)$ \\
\hline \multirow[t]{2}{*}{ Religiosity*competition } & & $-14.957 * * *$ & & $-.473 * * *$ \\
\hline & & $(4.672)$ & & $(.157)$ \\
\hline Regional effects & Yes & Yes & Yes & Yes \\
\hline Observations & 111 & 111 & 112 & 112 \\
\hline Adjusted R square & .746 & .765 & .820 & .832 \\
\hline F statistic & 58.71 & 50.12 & 92.20 & 83.19 \\
\hline RMSE & 13.080 & 12.653 & .444 & .432 \\
\hline Region joint $\mathrm{F}$ & $3.78^{* * *}$ & $2.81 * *$ & $8.77 * * *$ & $7.61 * * *$ \\
\hline
\end{tabular}

Note. All regressions include the full baseline of Table 2. Heteroscedasticity consistent standard errors in parentheses.

*** $P<.01$.

$* * P<.05$

$* P<.10$. 
Table 4

Comparing Heterogeneous Effects of Religiosity Across the Four Levels of Democracy

\begin{tabular}{lcccc}
\hline & \multicolumn{2}{c}{ Heritage Property Rights } & \multicolumn{2}{c}{ Kaufmann Rule of Law } \\
& OLS & 2SLS & OLS & 2SLS \\
\hline No political & 5.081 & -10.639 & .335 & -.191 \\
competition & $(12.495)$ & $(18.144)$ & $(.339)$ & $(.542)$ \\
Low competition & -9.876 & -21.445 & -.138 & $(.307)$ \\
& $(9.719)$ & $(14.186)$ & $-.611^{* *}$ & $(.417)$ \\
Some competition & $-24.832^{* * *}$ & $-32.252^{* * *}$ & $(.280)$ & $-.883^{* *}$ \\
Full competition & $(8.742)$ & $(11.603)$ & $-1.084^{* * *}$ & $(.347)$ \\
& $-39.789^{* * *}$ & $-43.059 * * *$ & $(.334)$ & $-1.229^{* * *}$ \\
\hline
\end{tabular}

Note. All regressions include the full baseline of Table 2. Heteroscedasticity consistent standard errors in parentheses.

$$
\begin{aligned}
& \text { *** } P<.01 . \\
& * * P<.05 \\
& * P<.10 .
\end{aligned}
$$


Table 5

Main and Interacted Results - 2SLS

\begin{tabular}{|c|c|c|c|c|}
\hline & \multicolumn{2}{|c|}{ Heritage Property Rights } & \multicolumn{2}{|c|}{ Kaufmann Rule of Law } \\
\hline & (1) & (2) & (3) & (4) \\
\hline \multirow[t]{2}{*}{ Political competition } & $3.809 * *$ & $11.586^{* * *}$ & $.153 * * *$ & $.415^{* * *}$ \\
\hline & $(1.692)$ & $(4.225)$ & $(.064)$ & $(.146)$ \\
\hline \multirow[t]{2}{*}{ Religiosity } & $-68.316 * * *$ & .168 & $-2.315^{* * *}$ & .155 \\
\hline & $(18.649)$ & $(22.772)$ & $(.637)$ & $(.693)$ \\
\hline \multirow[t]{2}{*}{ Religiosity*competition } & & $-10.807^{*}$ & & $-.346^{*}$ \\
\hline & & $(5.538)$ & & $(.182)$ \\
\hline Regional effects & Yes & Yes & Yes & Yes \\
\hline Observations & 111 & 105 & 112 & 106 \\
\hline Adjusted R square & .679 & .763 & .758 & .829 \\
\hline F statistic & 43.92 & 51.65 & 67.35 & 80.38 \\
\hline RMSE & 13.90 & 12.00 & .487 & .416 \\
\hline First stage partial R & .222 & $.417 / .624$ & .228 & $.369 / .608$ \\
\hline First stage F & 13.57 & $16.13 / 41.96$ & 14.00 & $15.65 / 42.07$ \\
\hline Hansen J stat & .309 & 1.206 & .170 & 1.179 \\
\hline
\end{tabular}

Note. All regressions include the full baseline of Table 2. Heteroscedasticity consistent standard errors in parentheses. All

IV results are estimated using limited information maximum likelihood. Instrumental variables are confidence in religious organizations and a Nordic dummy. First stage statistics with the interaction term refer first to religiosity, second to the interaction.

$$
\begin{aligned}
& \text { *** } P<.01 . \\
& \text { ** } P<.05 \\
& * P<.10 .
\end{aligned}
$$


Table 6

Interacted Results with Share of Non-Believers as Alternative Religiosity Measure

\begin{tabular}{lcccc}
\hline & \multicolumn{2}{c}{ Heritage Property Rights } & \multicolumn{2}{c}{ Kaufmann Rule of Law } \\
& $(1)$ & $(2)$ & $(3)$ & $(4)$ \\
\hline Political competition & $4.516^{* * *}$ & 2.259 & $.188^{* * *}$ & $.154^{* *}$ \\
& $(1.699)$ & $(1.914)$ & $(.064)$ & $(.070)$ \\
Non-believers & .066 & $-.439 * *$ & .003 & -.005 \\
& $(.086)$ & $(.172)$ & $(.002)$ & $(.004)$ \\
Non*competition & & $.177^{* * *}$ & & .003 \\
& & $(.056)$ & & $(.002)$ \\
Regional effects & Yes & Yes & Yes & Yes \\
\hline Observations & 106 & 106 & 106 & 106 \\
Adjusted R square & .739 & .755 & .819 & .821 \\
F statistic & 56.63 & 51.31 & 75.39 & 74.91 \\
RMSE & 13.248 & 12.912 & .454 & .453 \\
Region joint F & $3.00^{* *}$ & $2.84^{* *}$ & $8.25^{* * *}$ & $8.13^{* * *}$
\end{tabular}

Note. All regressions include the full baseline of Table 2. Heteroscedasticity consistent standard errors in parentheses.

$$
\begin{aligned}
& \text { *** } P<.01 . \\
& \text { ** } P<.05 \\
& \text { * } P<.10 .
\end{aligned}
$$


Table 7

Interacted Results with Weekly Worship as Alternative Religiosity Measure

\begin{tabular}{lcccc}
\hline & \multicolumn{2}{c}{ Heritage Property Rights } & \multicolumn{2}{c}{ Kaufmann Rule of Law } \\
& $(1)$ & $(2)$ & $(3)$ & $(4)$ \\
\hline Political competition & $4.201^{* * *}$ & $10.897^{* * *}$ & $.172^{* * *}$ & $.369^{* * *}$ \\
& $(1.514)$ & $(2.922)$ & $(.058)$ & $(.111)$ \\
Weekly worship & $-.166^{*}$ & .199 & -.004 & .007 \\
& $(.099)$ & $(.186)$ & $(.003)$ & $(.006)$ \\
Worship*competition & & $-.148^{* *}$ & & $-.004 * *$ \\
& & $(.059)$ & & $(.002)$ \\
Regional effects & Yes & Yes & Yes & Yes \\
\hline Observations & 111 & 111 & 112 & 112 \\
Adjusted R square & .741 & .754 & .818 & .825 \\
F statistic & 57.46 & 51.56 & 91.23 & 82.61 \\
RMSE & 13.207 & 12.941 & .446 & .440 \\
Region joint F & $4.46^{* * *}$ & $4.01 * * *$ & $9.79 * * *$ & $9.29 * * *$
\end{tabular}

Note. All regressions include the full baseline of Table 2. Heteroscedasticity consistent standard errors in parentheses.

$* * * P<.01$.

$* * P<.05$

$* P<.10$ 
Table 8

Interacted Results - Adding Control Variables

\begin{tabular}{|c|c|c|c|c|c|c|c|c|c|c|}
\hline & \multicolumn{5}{|c|}{ Heritage Property Rights } & \multicolumn{5}{|c|}{ Kaufmann Rule of Law } \\
\hline & (1) & (2) & (3) & (4) & $(5)$ & (6) & (7) & (8) & (9) & (10) \\
\hline Political & $14.038^{* * *}$ & $14.398^{* * *}$ & $14.780^{* * *}$ & $14.165^{* * *}$ & $12.511 * * *$ & $.482^{* * *}$ & $.492^{* * *}$ & $.493^{* * *}$ & $.488^{* * *}$ & $.445^{* * *}$ \\
\hline competition & $(3.362)$ & $(3.397)$ & $(3.398)$ & $(3.288)$ & $(3.532)$ & $(.119)$ & $(.119)$ & $(.117)$ & $(.118)$ & $(.117)$ \\
\hline \multirow[t]{2}{*}{ Religiosity } & $30.287^{*}$ & 20.689 & 23.831 & 21.598 & 21.194 & $1.229 * *$ & .805 & .730 & .839 & .847 \\
\hline & $(15.424)$ & $(16.013)$ & $(16.096)$ & $(15.978)$ & $(17.319)$ & $(.521)$ & $(.527)$ & $(.518)$ & $(.525)$ & $(.547)$ \\
\hline Religiosity* & $-14.331 * * *$ & $-15.157 * * *$ & $-15.654 * * *$ & $-14.780^{* * *}$ & $-13.901 * * *$ & $-.451 * * *$ & $-.472^{* * *}$ & $-.466 * * *$ & $-.466 * * *$ & $-.446^{* * *}$ \\
\hline competition & $(4.564)$ & $(4.649)$ & $(4.646)$ & $(4.656)$ & $(4.849)$ & $(.159)$ & $(.158)$ & $(.156)$ & $(.156)$ & $(.158)$ \\
\hline \multirow[t]{2}{*}{ IQ } & $.814^{* * *}$ & & & & & $.032 * * *$ & & & & \\
\hline & $(.309)$ & & & & & $(.011)$ & & & & \\
\hline \multirow[t]{2}{*}{ Government size } & & -.087 & & & & & .000 & & & \\
\hline & & $(.149)$ & & & & & $(. .05)$ & & & \\
\hline Government & & & $4.446^{* *}$ & & & & & .059 & & \\
\hline ideology & & & $(2.186)$ & & & & & $(.071)$ & & \\
\hline \multirow[t]{2}{*}{ Coups } & & & & $-.989 * *$ & & & & & $-.027 * *$ & \\
\hline & & & & $(.396)$ & & & & & $(.011)$ & \\
\hline \multirow[t]{2}{*}{ State religion } & & & & & $-7.192 * *$ & & & & & $-.191 *$ \\
\hline & & & & & $(3.121)$ & & & & & $(.101)$ \\
\hline Regional effects & Yes & Yes & Yes & Yes & Yes & Yes & Yes & Yes & Yes & Yes \\
\hline Observations & 111 & 111 & 110 & 111 & 111 & 112 & 112 & 110 & 112 & 112 \\
\hline Adjusted R square & .782 & .765 & .774 & .778 & .778 & .848 & .832 & .835 & .838 & .837 \\
\hline F statistic & 53.58 & 46.73 & 51.28 & 49.78 & 48.09 & 86.63 & 76.20 & 79.26 & 85.33 & 74.63 \\
\hline RMSE & 12.244 & 12.702 & 12.381 & 12.356 & 12.363 & .412 & .434 & .433 & .426 & .426 \\
\hline Region joint $\mathrm{F}$ & $4.50^{* * *}$ & $2.73^{* *}$ & $3.29 * *$ & $2.47 * *$ & $3.63^{* * *}$ & $13.37 * * *$ & $7.60^{* * *}$ & $7.83^{* * *}$ & $6.43^{* * *}$ & $7.60 * * *$ \\
\hline
\end{tabular}

Note. All regressions include the full baseline of Table 2. Heteroscedasticity consistent standard errors in parentheses.

$$
\begin{aligned}
& \text { *** } P<.01 . \\
& \text { ** } P<.05 \\
& * P<.10 .
\end{aligned}
$$


Table 9

Robustness Results - Excluding Potentially Influential Observations

\begin{tabular}{|c|c|c|c|c|c|c|}
\hline \multirow[b]{2}{*}{ Exclusion on: } & \multicolumn{3}{|c|}{ Heritage Property Rights } & \multicolumn{3}{|c|}{ Kaufmann Rule of Law } \\
\hline & Cook's D & Religiosity & Index & Cook's D & Religiosity & Index \\
\hline & (1) & (2) & (3) & (4) & (5) & (6) \\
\hline \multirow[t]{2}{*}{ Political competition } & $11.925^{* * *}$ & $17.741 * * *$ & $13.219 * * *$ & $.363^{* * *}$ & $.637 * * *$ & $.426^{* * *}$ \\
\hline & $(3.435)$ & $(4.514)$ & $(3.839)$ & $(.093)$ & $(.163)$ & $(.116)$ \\
\hline \multirow[t]{2}{*}{ Religiosity } & 5.431 & $44.126^{*}$ & 13.170 & .382 & $1.774 * *$ & .650 \\
\hline & $(14.895)$ & $(23.273)$ & $(15.062)$ & $(.417)$ & $(.783)$ & $(.489)$ \\
\hline \multirow[t]{2}{*}{ Religiosity*competition } & $-12.188^{* * *}$ & $-19.442 * * *$ & $-14.202^{* * *}$ & $-.331 * * *$ & $-.676 * * *$ & $-.472 * * *$ \\
\hline & $(4.457)$ & $(6.395)$ & $(5.003)$ & $(.122)$ & $(.226)$ & $(.158)$ \\
\hline Regional effects & Yes & Yes & Yes & Yes & Yes & Yes \\
\hline Observations & 105 & 91 & 89 & 105 & 92 & 90 \\
\hline Adjusted R square & .827 & .737 & .746 & .901 & .814 & .831 \\
\hline F statistic & 58.09 & 38.10 & 26.96 & 99.46 & 64.14 & 74.05 \\
\hline RMSE & 10.413 & 13.239 & 11.243 & .325 & .452 & .351 \\
\hline
\end{tabular}

Note. All regressions include the full baseline of Table 2. Heteroscedasticity consistent standard errors in parentheses.

Results in columns 1, 4 and 7 exclude observations with a Cook's D larger than 1.5 standard deviations.

$$
\begin{aligned}
& \text { *** } P<.01 . \\
& \text { ** } P<.05 \\
& * P<.10 .
\end{aligned}
$$




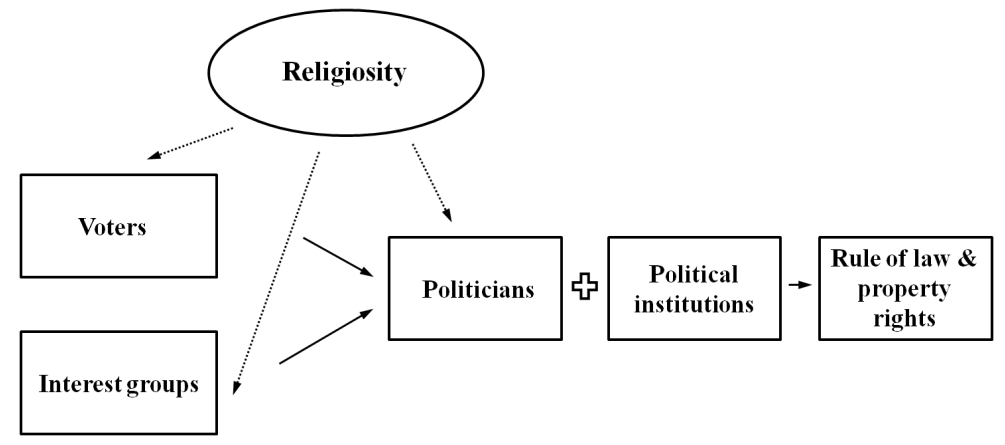

Figure 1. A simple model of religious influence on institutions 


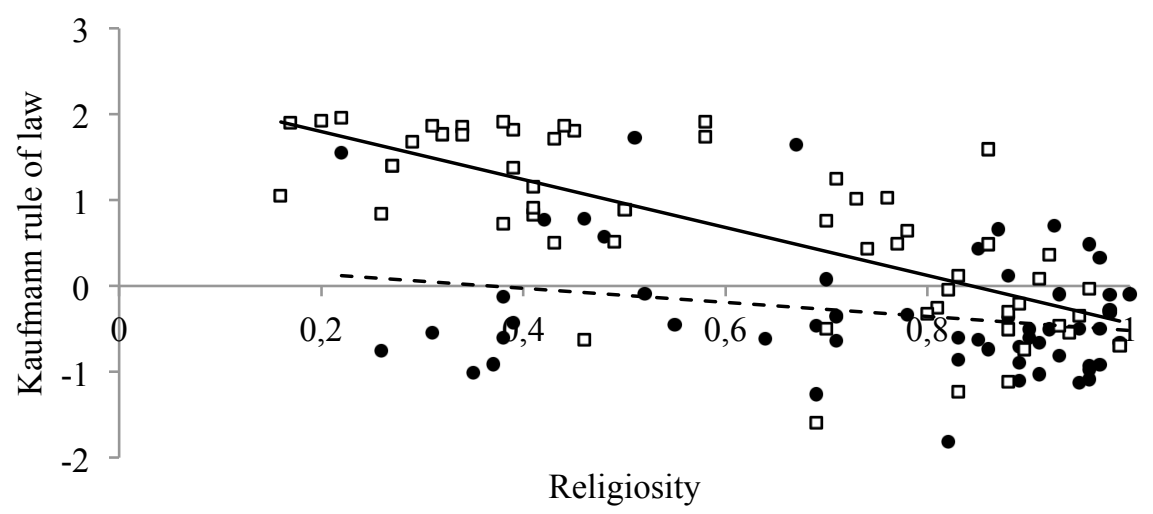

- Low competition $\quad$ High competition

Figure 2. Religiosity and the rule of law (Kaufmann) 